\title{
Study of the POU1f1 gene polymorphisms were associated with chicken growth traitsof Ross 308 broilers
}

\author{
${ }^{1}$ Ali H. Abdulwahid, ${ }^{2}$ Ali A.Abdulkareem,${ }^{3}$ Abdullah Hameed Salim \\ ${ }^{1,2,3}$ College of Agriculture and Marshes, University of Thi Qar, Iraq Corresponding authors \\ ${ }^{1}$ Email: ali.eaqen2017@gmail.com \\ ${ }^{2}$ Email: ali-ah@utq.edu.iq \\ ${ }^{3}$ Email: abdallah@utq.edu.iq
}

\section{Abstract:}

This experiment was conducted in the poultry field of the Department of Livestock at the College of Agriculture and Marshlands /University of Thi-Qar for 42 days from 13/11 to 24/12/2020. The experiment included raising 100 broiler chickens of Ross 308 strain. The aim of this study was to detect the polymorphism of the PIT-1 gene in exon 6 of ROSS 308 broilers and their relationship to production performance with some biochemical blood traits. The PIT-1 gene is a transcription factor specific to the anterior lobe of the pituitary gland, and is involved in pituitary cell differentiation and production by mediating transcription of Growth hormone (GH) and Prolactin (PRL) and thyroid hormone (TSH- $\beta$ ) stimulation which make it an important gene for its effect on the productive traits in broilers. DNA was extracted from 100 birds, and the polymerase chain reaction and the Sequencing technology of Nitrogen Bases were used and the detection of genetic mutations occurring in them, and the results showed the presence of a point mutation $(\mathrm{C} 1669 \mathrm{~T})$ in three genetic polymorphisms, namely CC , CT, and TT. There were highly significant differences $(\mathrm{P}>0.01)$ in the distribution ratios of genotypes, where the CC genotype scored the highest (82\%), followed by the CT genotype(12\%), and then the TT genotype $(6 \%)$, and that the allelic frequency of the $\mathrm{C}$ allele is superior to that of the $\mathrm{T}$ allele. where they were 0.88 and 0.12 , respectively, and it was found that there was a significant difference $(\mathrm{P}<0.05)$ for the genotypes of the mutation $(\mathrm{C} 1669 \mathrm{~T})$ on carcass weight, Dressing ratio, week body weight, relative breast weight, as well as serum total protein concentration at 42 days of age.

\section{Introduction}

Poultry birds are an important source for securing animal meat protein of high nutritional value among the different animals due to the balanced Amino Acids and low Cholesterol, in addition to its acceptable prices compared to the prices of Red meats and other animal products. Due to the increase in population growth rates, the demand for Poultry products was increase and this requires intensive and rapid breeding of broilers. Through the studies, it was found that $90 \%$ of the phenotypic differences between domestic birds are genetic, and thus poultry breeders focus on finding a commercial breed that gives the best growth performance in a short rearing period. There are two ways in which the genetic improvement of the breeds can be carried out using traditional methods, in which the animal is selected to conduct the cross-breed process depending on the breeding value(BV), which is expressed in productive efficiency, disease resistance, and reproduction, or by using Biotechnology through which animals with genetic phenotypes superior to that of their peers and the adoption of theme in spreading the genotypes in the herds more widely. Many genes have been used with the help of Molecular Markers to improve the productive performance of animals and this creates promising 


\section{University of Thi-Qar Journal of agricultural research}

ISSN Onlin:2708-9347, ISSN Print: 2708-9339 Volume 10, Issue 1 (2021) PP 25-38

https://jam.utq.edu.iq/index.php/main $\quad \underline{\text { https://doi.org/10.54174/UTJagr.Vo10.N1./03 }}$

opportunities for the development of genetic improvement programs and to obtain the best products with the help of genetic markers that have high accuracy in determining the Genetic Value of animals, and these methods provided opportunities for genetic improvement by increasing the growth rate and improving the quality of animals carcass ( Liu et al. 2005) and finding cross-breeding programs that can be adopted in genetic improvement programs by direct selection of the desired traits to obtain the best production. The Pit-1 gene is one of the most important genes that have been nominated as a gene that contains multiple polymorphisms (SNPs) affecting growth and productive traits in domestic birds ( Kulibaba et al. 2015). The role of the Pit-1 gene is essential for the production of growth hormone $(\mathrm{GH})$ in the pituitary gland, meaning that the synthesis of growth hormone fails in its absence( Harvey et al.1998), ( Pfaffle et al.1999), ( Wegner et al.1993). Several studies have been conducted on the multiple genetic polymorphisms of the Pit-1 gene through Restriction Fragment Length Polymorphism (RFLP) technology and deoxyribonucleic acid sequencing technology, and these molecular studies showed that when changing, deleting, or adding one nucleotide, it works to cause changes in the gene called single nucleotide polymorphisms (SNPs) a bi-allelic and widely spread along the genome in domestic birds and has been recently given attention after it was used as a molecular marker in the selection process, which reflected positively on the productive performance of animals ( Liu et al.2014).Due to the link of the gene Pit-1 with the productive and qualitative traits of broilers, the current study was conducted in order to detect the polymorphisms in the sixth axon of the Pit-1 gene and to find a relationship between it and the productive performance and some physiological traits in Ross 308 broilers using DNA sequencing technology.

\section{Materials and Methods:}

The experiment was conducted in the poultry field of the Department of Livestock at the Faculty of Agriculture and Marshlands -University of Thi-Qar. The experiment included raising 100 broiler chickens of Ross 308 strain for 42 days $(13 / 11$ to $24 / 12 / 2020)$. At the end of the breeding period, blood samples were taken to separate the DNA to determine the genotypes of the Pit-1 gene and study their relationship with the productive and physiological performance of birds. The laboratory work included DNA separation, electrophoresis and Polymerase Chain Reaction (PCR) in the laboratories of the College of Science / The University of Thi-Qar for the period 12/13/2020 to 2/3/2021. The biochemical blood characteristics were analyzed in Ibn Al-Baytar laboratory. Blood samples were drawn at the age of 42 days for 100 birds (using $5 \mathrm{ml}$ medical syringes of appropriate size for of the vein) from the wing vein, and placed in tubes containing an anticoagulant substance (EDTA). The samples were transferred to a cooler box using ice cubes and kept at a temperature of $-20 \mathrm{C}^{0}$ until molecular tests were performed on them. For the purpose of conducting physiological tests using serum, the blood was placed in special plastic tubes and left 30 minutes for the blood to clot and using a centrifuge (6000 cycles/min) for a period of 5 minutes, then, serum was separated and kept at a temperature of $-20 \mathrm{C}^{0}$ until physiological tests were performed. The concentration and purity of DNA was estimated, which is one of the most important processes that must be performed to evaluate the efficiency of the extraction process, using the Nano Drop Spectrophotometer, involved $1 \mathrm{ml}$ of genetic material was placed on the lens of the device and the absorbance of the sample was recorded at a wavelength of 260 / 280 nanometers. The acceptable DNA purity ratio is between 1.8-2, and the results of the samples examined by the computer linked to the spectrophotometer were included (Sambrook. 2001).For the purpose of knowing the polymorphisms of the Pit-1 gene, molecular detection was performed using the special Primers below. The primers concerned with the Pit-1 gene in exon 6 were prepared by Scientific Researcher Company in the form of lyophilized 
powder from two primers separated from each other, each of which is placed in a special tube with a label showing the sequence of nitrogen bases and how to prepare the primer for work.

Table 1:The primers sequencing in were used in the experiment .

\begin{tabular}{|c|c|c|c|}
\hline primers & Sequencing & $\begin{array}{c}\text { Amplicon } \\
\text { Length }\end{array}$ & Gene Bank \\
& $\left(\mathbf{5}^{\prime} \longrightarrow \mathbf{3}^{\prime}\right)$ & & \\
\hline $\begin{array}{c}\text { Forward } \\
\text { primer(pit-1) }\end{array}$ & 5-TGGGAAGAACAGTTTATGGC-3 & $483 \mathrm{~Pb}$ & NC-6088.5 \\
\hline $\begin{array}{c}\text { Reverse } \\
\text { primer(pit-1) }\end{array}$ & 5-TGGCTAGCTTGTAAGGGAATC-3 & & \\
\hline
\end{tabular}

Using the PCR gradient, six samples of DNA were placed in the PCR thermocycler and it was set at temperatures ranging from $57-62 \mathrm{C}^{0}$. The electrophoresis of the samples was carried out to ensure the presence of bands to determine the optimum temperature at which the association took place. After the required piece of the gene was obtained, which It was amplified by the PCR, and then the samples were sent to Microgene Corporation (South Korea) to analyze the sequence of nitrogenous bases to verify the presence or absence of the mutation. Data were statistically analyzed using the SAS- Statistical Analysis System (2012) program to study the effect of Genotypes (genetic morphology) of the Pit-1 mutation $(\mathrm{C} 1669 \mathrm{~T})$ on the productive traits of broilers, and the significant differences between the averages were compared using the polynomial Duncan 1955 test ( Duncan.1955).by applying the Least Square Means method.

Mathematical model:

$\mathrm{Yij}=\mu+\mathrm{Gi}+\mathrm{eij}$

Since:

Yij: the observation value (j) due to the genotype (i).

$\mu$ : the general mean of the experiment.

Gi: The effect of genetic phenotypes (TT, CT, CC) of the Pit-1 gene in ROSS 308 broilers.

e. ${ }^{2}$ eij: the random error that is normally distributed with a mean equal to zero and a variance of $(\sigma)$ 


\section{University of Thi-Qar Journal of agricultural research}

ISSN Onlin:2708-9347, ISSN Print: 2708-9339 Volume 10, Issue 1 (2021) PP 25-38

https://jam.utq.edu.iq/index.php/main $\quad$ https://doi.org/10.54174/UTJagr.Vo10.N1./03

\section{Results and Discussion:}

The process of extracting DNA from the blood of broilers was completed, and clear bundles of the extracted DNA were obtained by the electrophoresis process. The piece to be studied was extracted from the DNA and the PIT-1 hybrid exon number 6 , the length of the required piece $(483 \mathrm{~Pb})$ using the primers and the target piece was doubled From the gene by PCR technique, using a piece of known size (DNA Marker) that was placed in the first hole of the gel 3\% agarose to ensure the presence of the bundles (Figure 1). After electrophoresis, the results of the PCR volume of 20 microliters were sent to Microgen Company in Korea Microgen Corporation - Korea, in order to read the sequence of nitrogenous bases and detect the occurrence of genetic mutations. The results were sent by E-mail, where the Genious Software program was used for the purpose of analyzing the results at the Global website of the Gene Bank www.ncbi.nim.nih.go and through the nucleotide sequence files and wavelength curves file, it was confirmed that the location of the mutations of the Pit-1 gene was identified ( Figure2).

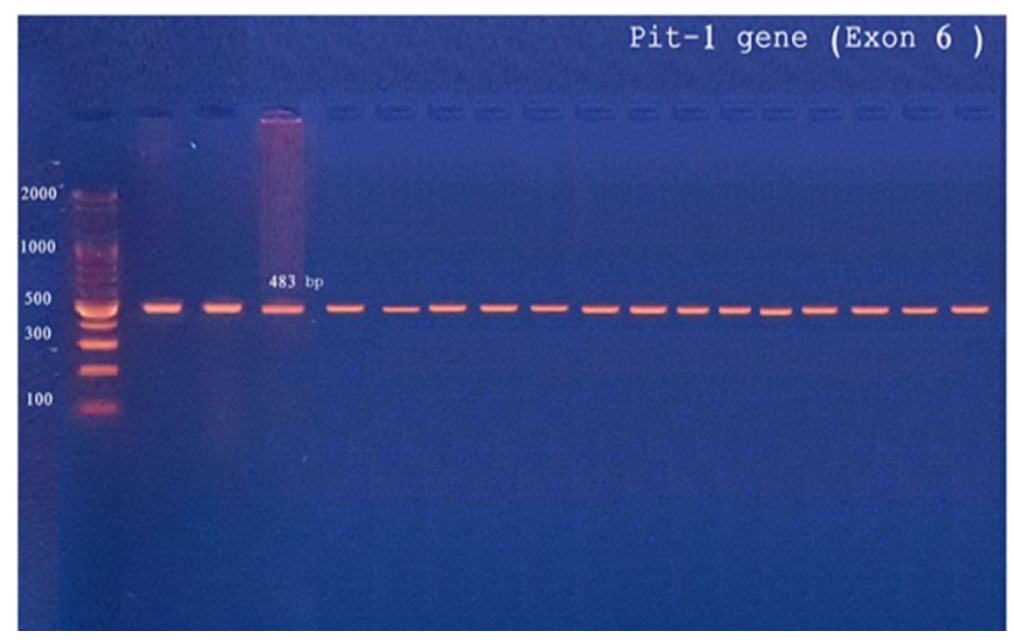

Figure1. The polymerase chain reaction (PCR) product of the amplified segment of the Pit-1 483pb on a $3 \%$ agarose gel at $50 \mathrm{~V}$ for 1.5 hours and exposing the Ethidium Bromide-stained agarose gel to a UV device. 


\section{University of Thi-Qar Journal of agricultural research}

ISSN Onlin:2708-9347, ISSN Print: 2708-9339 Volume 10, Issue 1 (2021) PP 25-38

https://jam.utq.edu.iq/index.php/main $\quad$ https://doi.org/10.54174/UTJagr.Vo10.N1./03

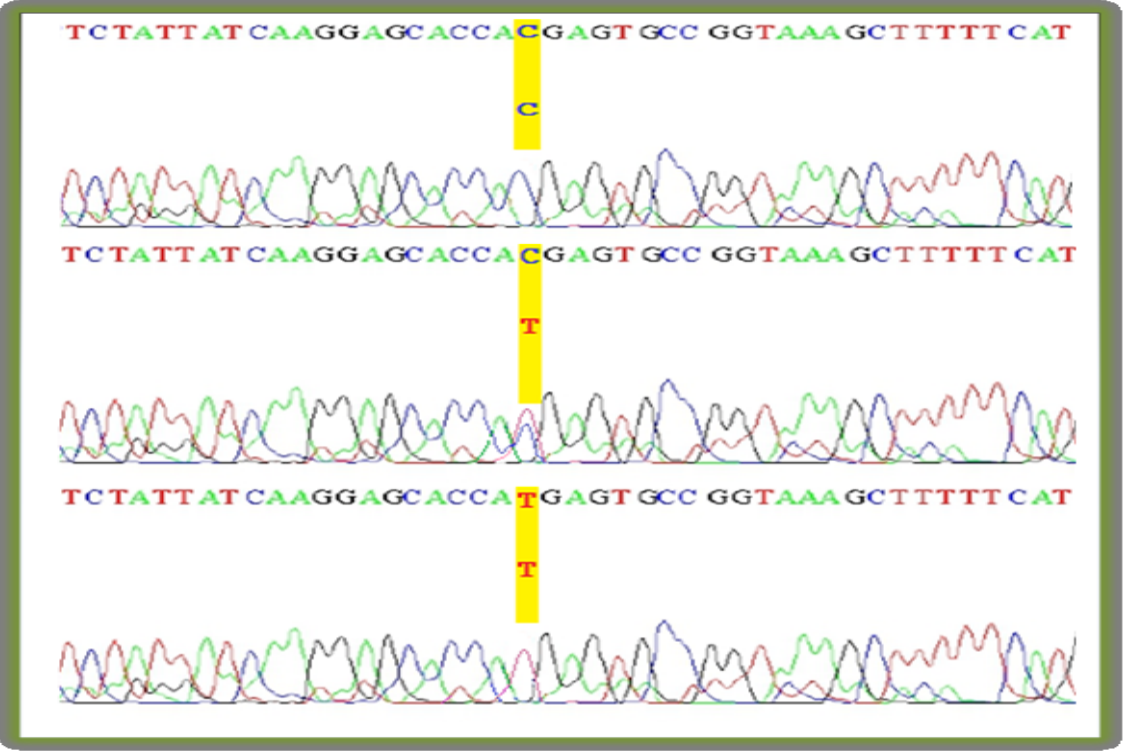

Figure 2: The site of the mutation (C1669T) of the Pit-1 gene (Exon 6)

It is clear from Table (2) the distribution of the different genetic phenotypes of the Pit-1 gene for genetic variation at the C1669T locus in broilers, which shows that there are highly significant differences $(\mathrm{P}<0.01)$ in the proportions of genotypes, and an obvious prevalence of individuals carrying the genotype CC ( $82 \%$ ), followed by CT genotype (12\%), while TT genotype had the lowest percentage (6\%). The frequency of the $\mathrm{C}$ allele was 0.88 and the $\mathrm{T}$ allele was 0.12 according to Hardy-Weinberg equilibrium law. The results of our study matched with ( Manjula et al.2018) .on Korean Native Chicken for the Pit-1 exon 6 gene, where a significant effect was found $(\mathrm{P}<0.05)$ with the $\mathrm{CC}$ genotype having the highest percentage of $85 \%$, CT genotype (13\%), and the TT genotype (2\%), and the allelic frequency of the wild C allele was 0.91 and 0.09 frequency of the mutant allele T. Also corresponded with ( Nguyen et al.2021).when studying the same region of the gene in local Vietnamese (Noa) chickens, where the mutation C1041T was detected, and it was found that there were highly significant differences $(\mathrm{P} \leq 0.01)$, where the $\mathrm{CT}$ genotype recorded the highest percentage (79\%), followed by the TT genotype with a percentage of $17 \%$, while the CC genotype had the lowest percentage of $4 \%$. It was found that the wild allelic frequency $\mathrm{C}$ is 0.61 and the mutant allele $\mathrm{T}$ is 0.39 according to the Hardy and Weinberg equilibrium. The results of Table (3) showed that there were no significant differences between the genotypes TT, TC, CC of the Pit-1 gene in the average body weight on the first day of the bird's life and the first and second weeks old, while the third week showed a significant superiority $(p \leq 0.05)$ for each of the two genotypes CC and CT over the TT genotype, which had their rates of 799.90, 769.0 and $596.66 \mathrm{gm}$, respectively, while in the fourth week it showed a significant ( $\mathrm{p} \leq 0.05)$ superiority for the CC genotype(1334.83 gm) compared to the TT genotype(1011.33gm) while the CT (1156.83 gm) genotype showed no significant difference with the other genotypes. The CC genotype continued to be superior in the fifth and sixth week over the CT and TT genotypes, respectively, while there was no significant superiority between the CT and TT genotypes for the same period, and their averages in the sixth week were 1696.17 and 1721.0 gm, respectively. 
Table 2: The number, percentage and allelic frequency of the genetic variation of the Pit-1 gene (C1669T) in ROSS 308 broilers.

\begin{tabular}{|c|c|c|c|c|}
\hline Mutation & Genotypes & Number & $(\%)$ & $\begin{array}{c}\text { Allelic } \\
\text { frequency }\end{array}$ \\
\hline \multirow{3}{*}{$\mathrm{C} / \mathbf{T}$} & $\mathrm{CC}$ & 41 & 82 & \multirow{4}{*}{$\begin{aligned} \mathbf{C} & =\mathbf{0 . 8 8} \\
\mathbf{T} & =\mathbf{0 . 1 2}\end{aligned}$} \\
\hline & CT & 6 & 12 & \\
\hline & TT & 3 & 6 & \\
\hline \multicolumn{2}{|l|}{ Total } & 50 & 100 & \\
\hline \multicolumn{5}{|c|}{$($ Chi-Square $)=41.68^{* *}$} \\
\hline
\end{tabular}

\section{$* *(\mathbf{P} \leq \mathbf{0 . 0 1})$}

Our study corresponded with ( Manjula et al.2018). which was conducted on Korean Native Chicken for the Pit-1 exon 6 gene, where there was a significant effect $(\mathrm{P} \leq 0.05)$ on body weight at $14-18$ weeks with the superiority of the CC genotype over the TT genotype, while the CT genotype did not show significant differences with the rest of the genotypes. The current study agreed with ( Nguyen et al.2021).for the Pit-1 gene in exon 6, as it was found that it was significantly associated with body weight at the age of 91-64 days in the Vietnamese Noa chicken with the superiority of the genotype TT followed by Genotype CT and then genotype CC, and our study was close to ( Nie et al.2008). in his research on the Pit-1 gene in exon 6 on a two-line hybrid of Chinese chicken (CX) and (WRR). 
ISSN Onlin:2708-9347, ISSN Print: 2708-9339 Volume 10, Issue 1 (2021) PP 25-38

https://jam.utq.edu.iq/index.php/main $\quad$ https://doi.org/10.54174/UTJagr.Vo10.N1./03

Table 3: Relationship of the polymorphism of the PIT-1 gene (C1669T) with the body weight of ROSS 308 broilers (Mean \pm Standard error).

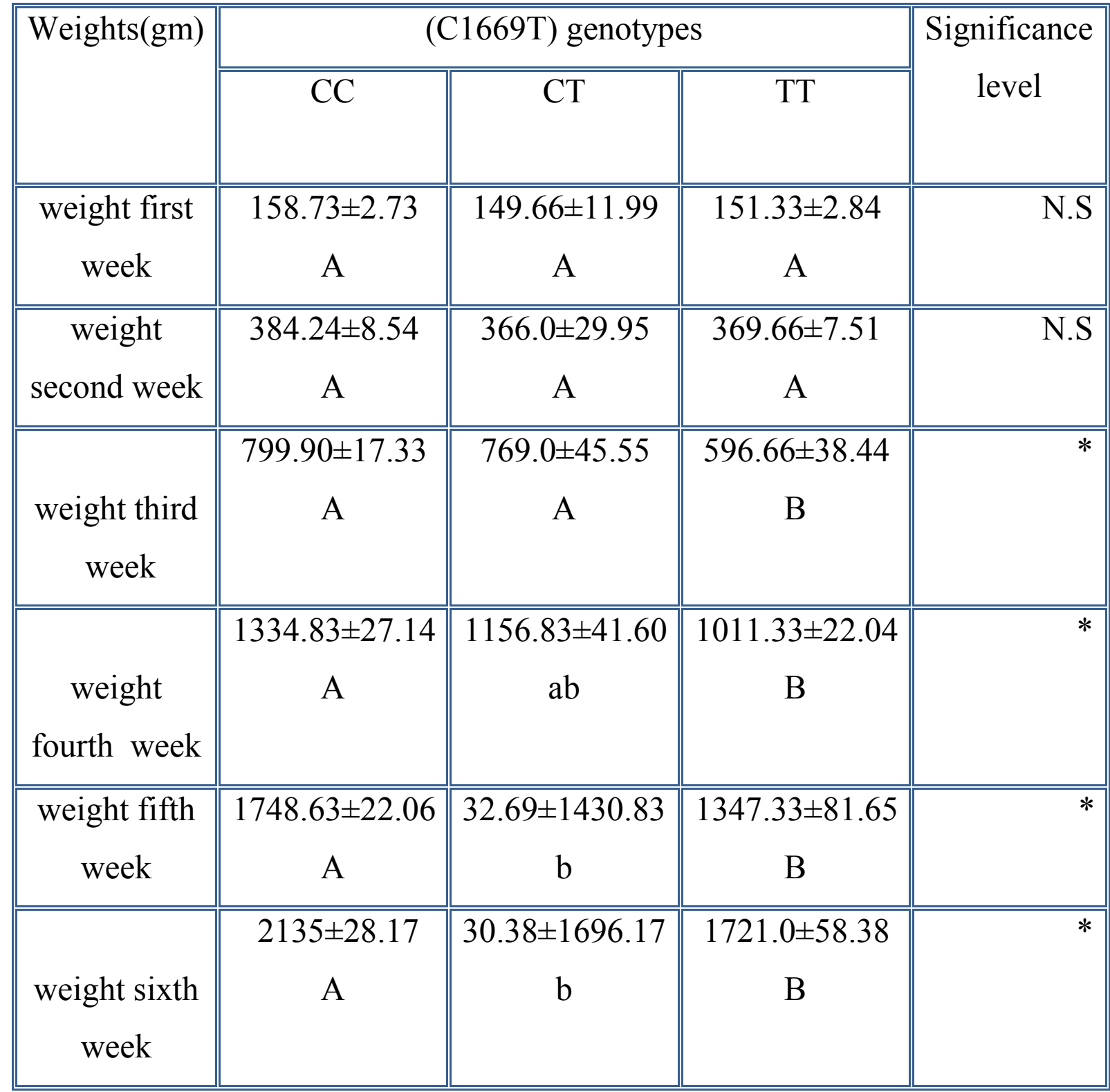

N.S: Not significant, *: The averages with different letters within the same row differ significantly $(\mathrm{P} \leq 0.05)$.

Table (4) shows that there were no significant differences in the rate of weight gain in the first, second, third and sixth weeks, and the CC genotype was significantly superior $(\mathrm{p} \leq 0.05)$ in the fourth week at $534.92 \mathrm{gm}$, while in the fifth week, the CC genotype showed a significant $(\mathrm{p} \leq 0.05)$ superiority compared to the CT genotype, as their averages reached 413.80 and $274.00 \mathrm{gm}$, respectively, and the TT phenotype showed no significant differences with the other phenotypes, with an average of $336.00 \mathrm{gm}$. Our study corresponded with (Manjula et al.2018) .which was conducted on Korean Native Chicken for the Pit-1 gene, where it was found that there was a significant effect $(\mathrm{P} \leq 0.05)$ in the characteristic of the weekly weight gain for the period 14-16 weeks in favor of the CC genotype by its superiority over The TT genotype, while the CT genotype did not show a significant difference with the rest of the other genotypes, 


\section{University of Thi-Qar Journal of agricultural research}

ISSN Onlin:2708-9347, ISSN Print: 2708-9339 Volume 10, Issue 1 (2021) PP 25-38

https://jam.utq.edu.iq/index.php/main $\quad$ https://doi.org/10.54174/UTJagr.Vo10.N1./03

while in the period 16-18 weeks, the weekly weight gain was in favor of the CC genotype, which amounted to $217.90 \mathrm{~g}$, which outperformed the CT and TT genotypes, whose average weight was 185.32 and $162.97 \mathrm{~g}$, respectively. These results agreed with the study of 9 and 11.The difference in the results of previous studies with the current study may be due to the difference in the studied region of the gene, as well as the difference in the strains that were used. It is noticed from Table $(5)$ that there is a significant difference $(\mathrm{p} \leq 0.05)$ in the average slaughter weight in favor of the CC genotype, as its average was $1901.07 \mathrm{gm}$ compared with the two genotypes CT and TT (1504 and 1518.33 gm, respectively), and it was found that there is a significant difference $((\mathrm{p} \leq 0.05)$ in the ratios of dressing 1 ( with edible viscera) and ratio of dressing 2 (without edible viscera), as the ratio of dressing 1 reached the highest percentage of CC genotype over TT genotype, with 79.68 and 76.89 gm, respectively, while the genotype CT with no significant difference with the rest of the genotypes.

Table 4: The relationship of the polymorphism of the Pit-1 gene (C1669T) with the weekly weight gain rate of ROSS 308 broilers (Mean \pm Standard error) .

\begin{tabular}{|c|c|c|c|c|}
\hline \multirow{2}{*}{$\begin{array}{c}\text { weekly } \\
\text { weight gain }\end{array}$} & \multicolumn{3}{|c|}{ (C1669T) genotypes } & \multirow{2}{*}{$\begin{array}{c}\text { Significance } \\
\text { level }\end{array}$} \\
\hline & CC & $\overline{\mathrm{CT}}$ & TT & \\
\hline \multirow[t]{2}{*}{ Week 1} & $118.25 \pm 2.76$ & $109.35 \pm 12.22$ & $111.73 \pm 2.65$ & N.S \\
\hline & A & A & A & \\
\hline \multirow[t]{2}{*}{ Week 2} & $225.51 \pm 6.58$ & $216.33 \pm 24.69$ & $218.33 \pm 8.41$ & N.S \\
\hline & A & A & A & \\
\hline \multirow[t]{2}{*}{ Week 3} & $415.65 \pm 13.59$ & $403.00 \pm 18.12$ & $326.00 \pm 33.50$ & N.S \\
\hline & A & A & A & \\
\hline \multirow[b]{2}{*}{ Week 4} & $534.92 \pm 16.51$ & $387.83 \pm 25.77$ & $414.66 \pm 16.70$ & \\
\hline & A & B & B & $*$ \\
\hline \multirow[b]{2}{*}{ Week 5} & $413.80 \pm 15.33$ & $274.00 \pm 37.95$ & $336.00 \pm 65.15$ & \\
\hline & A & B & $\mathrm{Ab}$ & $*$ \\
\hline \multirow[t]{3}{*}{ Week 6} & 386.73 & $265.33 \pm 26.25$ & $373.66 \pm 91.62$ & N.S \\
\hline & \pm 15.12 & A & $\mathrm{A}$ & \\
\hline & A & & & \\
\hline
\end{tabular}


N.S: Not significant, *: The averages with different letters within the same row differ significantly $(\mathrm{P} \leq 0.05)$. It was found that there was a significant difference $(p \leq 0.05)$ for the relative weight of the chest in favor of the genotype CC ( $32.75 \mathrm{gm}$ ) on the TT genotype of $29.71 \mathrm{gm}$, and there were no significant differences for the CT genotype with the other two genotypes in this trait, while the rest of the relative weights For thigh, drummer, wings, neck, back and belly fat, no significant differences were observed for the different genotypes. These results were close to the study of ( Nguyen et al.2021).on the Pit-1 gene in exon 6, where it was found that there was a significant increase in the average weight of the chest muscle for the TT genotype over the CT genotype, followed by the CC genotype, and differed from our study by the presence of a significant $(\mathrm{p} \leq 0.05)$ increase in the mean thigh weight of the TT genotype over the CT genotype, followed by the CC genotype, and there was no significant effect of the genotypes on the dressing ratio, and this difference may be due to the difference between the strain that it was used, or due to the presence of another mutation within the same gene, or due to the effect of another gene on growth, which had a positive effect on the relative weight of the thigh muscle. Table $(6)$ shows that there is a significant difference $(p \leq 0.05)$ in the total protein concentration in favor of the CC genotype, which amounted to $3.91 \mathrm{~g} / 100 \mathrm{ml}$ blood on the CT and TT genotypes, with their rates being 3.28 and $3.34 \mathrm{~g} / 100 \mathrm{ml}$ blood respectively, while we did not find a significant effect in measuring the concentrations of the rest of the other blood traits. The current study coincided with (Nguyen et al.2021) and ( Rodbari et al.2011) where they found through research that the occurrence of mutations in the Pit-1 gene directly affected the level of growth hormone and Prolactin and TSH- $\beta$ (thyroid stimulating hormone type $\beta$ ) ( Bhattacharya et al.2012).and that increasing in the level of Growth hormone increases protein synthesis and reduces the process of its degradation and oxidation, and this leads to increased protein growth . ( AL-kreem et al.2017).It is noted from table (7) that there are no significant differences for the genotypes CC, CT and TT of the Pit-1 gene in exon 6 with the relative

Table 5: The relationship of genetic phenotypes of the (C1669T) gene with the dressing ratios and the relative weight of the studied cuts of ROSS 308 broilers (Mean \pm Standard error)

\begin{tabular}{|c|c|c|c|c|}
\hline \multirow[t]{2}{*}{ Traits } & \multicolumn{3}{|c|}{ (C1669T) genotypes } & \multirow{2}{*}{$\begin{array}{c}\text { Significance } \\
\text { level }\end{array}$} \\
\hline & $\mathbf{C C}$ & CT & TT & \\
\hline Dressing ratio 1 & $\begin{array}{c}0.30+79.68 \\
\text { A }\end{array}$ & $\begin{array}{c}1.09+78.54 \\
\mathrm{ab}\end{array}$ & $\begin{array}{c}0.47+76.89 \\
b\end{array}$ & $*$ \\
\hline Dressing ratio 2 & $\begin{array}{c}0.27+74.31 \\
\text { A }\end{array}$ & $\begin{array}{c}1.11+72.46 \\
\mathrm{ab}\end{array}$ & $\begin{array}{c}0.37+71.36 \\
\text { b }\end{array}$ & $*$ \\
\hline $\begin{array}{c}\text { Carcass weight } \\
\text { (gm) }\end{array}$ & $\begin{array}{c}25.73+1901.07 \\
\text { A }\end{array}$ & $\begin{array}{c}24.87+1504 \\
\text { b }\end{array}$ & $\begin{array}{c}58.59+1518.33 \\
b\end{array}$ & $*$ \\
\hline Thigh relative & $0.19+11.85$ & $0.79+12.26$ & $0.32+13.08$ & N.S \\
\hline
\end{tabular}




\section{University of Thi-Qar Journal of agricultural research}

ISSN Onlin:2708-9347, ISSN Print: 2708-9339 Volume 10, Issue 1 (2021) PP 25-38

https://jam.utq.edu.iq/index.php/main $\quad \underline{\text { https://doi.org/10.54174/UTJagr.Vo10.N1./03 }}$

\begin{tabular}{|c|c|c|c|c|}
\hline weight(gm) & A & $\mathrm{a}$ & $\mathrm{a}$ & \\
\hline $\begin{array}{c}\text { Drummer relative } \\
\text { weight(gm) }\end{array}$ & $\begin{array}{c}0.13+10.58 \\
\text { A }\end{array}$ & $\begin{array}{c}0.36+10.60 \\
\mathrm{a}\end{array}$ & $\begin{array}{c}0.40+11.28 \\
\mathrm{a}\end{array}$ & N.S \\
\hline $\begin{array}{l}\text { Wings relative } \\
\text { weight(gm) }\end{array}$ & $\begin{array}{c}0.12+7.77 \\
\mathrm{~A}\end{array}$ & $\begin{array}{c}0.19+8.06 \\
a\end{array}$ & $\begin{array}{c}0.36+8.67 \\
a\end{array}$ & N.S \\
\hline $\begin{array}{l}\text { Neck relative } \\
\text { weight }(\mathrm{gm})\end{array}$ & $\begin{array}{c}0.05+2.98 \\
\mathrm{~A}\end{array}$ & $\begin{array}{c}0.16+3.32 \\
a\end{array}$ & $\begin{array}{c}0.19+3.13 \\
\mathrm{a}\end{array}$ & N.S \\
\hline $\begin{array}{l}\text { Back relative } \\
\text { weight(gm) }\end{array}$ & $\begin{array}{c}0.28+14.11 \\
\mathrm{~A}\end{array}$ & $\begin{array}{c}0.82+14.11 \\
\mathrm{a}\end{array}$ & $\begin{array}{c}0.08+15.25 \\
a\end{array}$ & N.S \\
\hline belly fat(gm) & $\begin{array}{c}0.08+1.46 \\
\mathrm{~A}\end{array}$ & $\begin{array}{c}0.21+1.37 \\
\mathrm{a}\end{array}$ & $\begin{array}{c}0.09+1.56 \\
\mathrm{a}\end{array}$ & N.S \\
\hline $\begin{array}{l}\text { Chest relative } \\
\text { weight(gm) }\end{array}$ & $\begin{array}{c}0.33+32.75 \\
\mathrm{~A}\end{array}$ & $\begin{array}{c}0.65+30.81 \\
\mathrm{Ab}\end{array}$ & $\begin{array}{c}0.69+29.71 \\
b\end{array}$ & $*$ \\
\hline
\end{tabular}

N.S: Not significant, *: The averages with different letters within the same row differ significantly $(\mathrm{P} \leq 0.05)$. Dressing 1(with edible viscera),ratio of dressing 2 (without edible viscera).

weight of the eaten parts and the body circumference measurements studied for broilers ROSS 308 except for measuring body length, where it was found that there is a significant increase $(\mathrm{p} \leq 0.05)$ in favor of the CC genotype by $56.01 \mathrm{~cm}$ on the two genotypes CT and TT (52.90 and $52.33 \mathrm{~cm}$, respectively), and our study was close to ( AL-Anbari.2019).which was done on the ROSS 308 strain when studying the multiple genotypes of the PIT- gene 1 in intron 5 by RFLP-PCR method, where he did not find significant differences with the relative weight of the eaten parts and the physical measurements. These results were close to the study of ( Nguyen et al.2021).on the Pit-1 gene in exon 6 in the Vietnamese Noa chicken, where it was found that there was a significant increase $(p \leq 0.05)$ in the average thigh circumference in favor of the TT genotype over the two genotypes CT and CC, and no significant differences were found. In the rest of the physical characteristics and the edible parts, the difference in results between the multiple genotypes of the Pit-1 gene and the weight of the eaten parts may be due to the difference in the studied region of the gene as well as the difference in the strains that were used to conduct research, and this would result in a difference in effect of mutations of the Pit-1 gene on the gene expression of the gene. Finally, it can be concluded that the genetic polymorphism of the Pit1 gene in exon 6 can be a distinctive genetic indicator for selection for important economic traits in ROSS 308 broilers and relying on it in future genetic improvement programs in this breed. 


\section{University of Thi-Qar Journal of agricultural research}

ISSN Onlin:2708-9347, ISSN Print: 2708-9339 Volume 10, Issue 1 (2021) PP 25-38

https://jam.utq.edu.iq/index.php/main $\quad$ https://doi.org/10.54174/UTJagr.Vo10.N1./03

Table 6: Relationship of the genotypes of the Pit-1 gene (T1669C) with the blood characteristics of ROSS 308 broilers (Mean \pm Standard error).

\begin{tabular}{|c|c|c|c|c|}
\hline \multirow{2}{*}{$\begin{array}{c}\text { Traits } \\
\text { ( mg/100ml } \\
\text { blood) }\end{array}$} & \multicolumn{3}{|c|}{ (C1669T) genotypes } & \multirow{2}{*}{$\begin{array}{c}\text { Significant } \\
\text { level }\end{array}$} \\
\hline & $\mathrm{CC}$ & $\mathrm{CT}$ & $\mathrm{TT}$ & \\
\hline Glucose & $\begin{array}{c}225.00 \pm 13.36 \\
\mathrm{~A}\end{array}$ & $\begin{array}{c}235.33 \pm 6.47 \\
\text { A }\end{array}$ & $\begin{array}{c}238.66 \pm 2.90 \\
a\end{array}$ & N.S \\
\hline Total protein & $\begin{array}{c}3.91 \pm 0.10 \\
\text { A }\end{array}$ & $\begin{array}{c}3.28 \pm 0.03 \\
\text { B }\end{array}$ & $\begin{array}{c}3.34 \pm 0.04 \\
b\end{array}$ & $*$ \\
\hline Cholesterol & $\begin{array}{c}211.71 \pm 14.10 \\
\text { A }\end{array}$ & $\begin{array}{c}226.33 \pm 21.47 \\
\text { A }\end{array}$ & $\begin{array}{c}204.33 \pm 24.83 \\
\mathrm{a}\end{array}$ & N.S \\
\hline Triglycerides & $\begin{array}{c}129.85 \pm 3.82 \\
\mathrm{~A}\end{array}$ & $\begin{array}{c}127.83 \pm 3.00 \\
\mathrm{~A}\end{array}$ & $\begin{array}{c}130.66 \pm 3.17 \\
\mathrm{a}\end{array}$ & N.S \\
\hline $\mathrm{Na}$ & $\begin{array}{c}102.625 .96 \pm \\
\mathrm{A}\end{array}$ & $\begin{array}{c}93.30 \pm 5.00 \\
\mathrm{~A}\end{array}$ & $\begin{array}{c}94.100 \pm 6.26 \\
\mathrm{a}\end{array}$ & N.S \\
\hline $\mathrm{Ca}$ & $\begin{array}{c}3.05 \pm 0.22 \\
\mathrm{~A}\end{array}$ & $\begin{array}{c}2.93 \pm 0.09 \\
\text { A }\end{array}$ & $\begin{array}{c}3.03 \pm 0.09 \\
\mathrm{a}\end{array}$ & N.S \\
\hline $\mathrm{Zn}$ & $\begin{array}{c}43.85 \pm 3.14 \\
\mathrm{~A}\end{array}$ & $\begin{array}{c}46.33 \pm 1.11 \\
\mathrm{~A}\end{array}$ & $\begin{array}{c}51.33 \pm 1.45 \\
\mathrm{a}\end{array}$ & N.S \\
\hline $\mathrm{Cu}$ & $\begin{array}{c}9.20 \pm 5.36 \\
\mathrm{~A}\end{array}$ & $\begin{array}{c}93.70 \pm 6.06 \\
\mathrm{~A}\end{array}$ & $\begin{array}{c}96.73 \pm 7.15 \\
a\end{array}$ & N.S \\
\hline
\end{tabular}

N.S: Not significant, ${ }^{*}$ : The averages with different letters within the same row differ significantly $(\mathrm{P} \leq 0.05)$. 
ISSN Onlin:2708-9347, ISSN Print: 2708-9339 Volume 10, Issue 1 (2021) PP 25-38

https://jam.utq.edu.iq/index.php/main $\quad$ https://doi.org/10.54174/UTJagr.Vo10.N1./03

Table 7: The relationship of genotypes of the the Pit-1 gene (T1669C) with the relative weight of the parts eaten and body circumference measurements of ROSS 308 broilers (Mean \pm Standard error).

\begin{tabular}{|c|c|c|c|c|}
\hline \multirow[t]{2}{*}{ Traits } & \multicolumn{3}{|c|}{ (C1669T) genotypes } & \multirow[b]{2}{*}{ Significant level } \\
\hline & $\mathbf{C C}$ & CT & TT & \\
\hline $\begin{array}{c}\text { The relative weight } \\
\text { of the heart }\end{array}$ & $\begin{array}{c}0.49 \pm 0.003 \\
\mathrm{~A}\end{array}$ & $\begin{array}{c}0.53 \pm 0.009 \\
\mathrm{~A}\end{array}$ & $\begin{array}{c}0.5 \pm 0.005 \\
\mathrm{a}\end{array}$ & N.S \\
\hline $\begin{array}{c}\text { The relative weight } \\
\text { of the liver }\end{array}$ & $\begin{array}{c}2.43 \pm 0.04 \\
\mathrm{~A}\end{array}$ & $\begin{array}{c}2.59 \pm 0.15 \\
a\end{array}$ & $\begin{array}{c}2.55 \pm 0.03 \\
\mathrm{a}\end{array}$ & N.S \\
\hline $\begin{array}{c}\text { Relative weight of } \\
\text { the Gizzard }\end{array}$ & $\begin{array}{c}2.43 \pm 0.03 \\
\mathrm{~A}\end{array}$ & $\begin{array}{c}2.65 \pm 0.04 \\
\mathrm{a}\end{array}$ & $\begin{array}{c}2.47 \pm 0.06 \\
a\end{array}$ & N.S \\
\hline *body length/cm & $\begin{array}{c}56.01 \pm 0.10 \\
\mathrm{~A}\end{array}$ & $\begin{array}{c}52.90 \pm 0.75 \\
\text { b }\end{array}$ & $\begin{array}{c}52.33 \pm 0.66 \\
\text { b }\end{array}$ & * \\
\hline $\begin{array}{c}\text { body } \\
\text { circumference/cm }\end{array}$ & $\begin{array}{c}41.61 \pm 0.45 \\
\text { A }\end{array}$ & $\begin{array}{c}40.71 \pm 0.52 \\
a\end{array}$ & $\begin{array}{c}39.23 \pm 0.12 \\
a\end{array}$ & N.S \\
\hline chest length/cm & $\begin{array}{c}12.73 \pm 0.07 \\
\mathrm{a}\end{array}$ & $\begin{array}{c}12.77 \pm 0.11 \\
\mathrm{a}\end{array}$ & $\begin{array}{c}12.55 \pm 0.05 \\
\mathrm{a}\end{array}$ & N.S \\
\hline thigh width/cm & $\begin{array}{c}3.49 \pm 0.06 \\
\mathrm{~A}\end{array}$ & $\begin{array}{c}3.39 \pm 0.11 \\
\mathrm{a}\end{array}$ & $\begin{array}{c}3.54 \pm 0.20 \\
\mathrm{a}\end{array}$ & N.S \\
\hline
\end{tabular}

N.S: Not significant, $*$ : The averages with different letters within the same row differ significantly $(\mathrm{P} \leq 0.05)$. 


\section{University of Thi-Qar Journal of agricultural research}

ISSN Onlin:2708-9347, ISSN Print: 2708-9339 Volume 10, Issue 1 (2021) PP 25-38

https://jam.utq.edu.iq/index.php/main $\quad$ https://doi.org/10.54174/UTJagr.Vo10.N1./03

\section{References}

1- Liu K. Muse SV (2005). PowerMarker: an integrated analysis environment for genetic marker analysis, Bioinformatics, 21 (9): 21282129

2-Kulibaba,R. A.and Tereshchenko (2015). Polymorphism of growth hormone, growth hormone receptor, prolactin and prolactin receptor genes in connection with egg production in Poltava clay chicken. Sci. 62, $1584-1595$

3-Harvey, S., Johnson, C. D. M., Sharma, P., Sanders, E. J., \& Hull, K. L. (1998). Growth hormone: a paracrine growth factor in embryonic development?. Comparative Biochemistry and Physiology Part C: Pharmacology, Toxicology and Endocrinology, 119(3), 305-315.

4-Pfaffle C. Kim, R. W.,., Blankenstein, O., \& Kentrup, H. (1999). GH transcription factors. Journal of pediatric endocrinology \& metabolism: JPEM, 12, 311-317

5-Wegner, M., Drolet, D. W., \& Rosenfeld, M. G. (1993). POU-domain proteins: structure and function of developmental regulators. Current opinion in cell biology, 5(3), 488-498

6- Liu, Lv, J., P., Gao, B., Wang, Y., Wang, Z., Chen, P., \& Li, J. (2014). Transcriptome analysis of the Portunus trituberculatus: de novo assembly, growth-related gene identification and marker discovery. PLoS one, 9(4), e94055.

7-Sambrook, J. (2001). Preparation and analysis of Eukaryotic Genome DNA. Molecular cloning: a laboratory manual, 1, 6-1

8- Duncan, D.D. (1955). Multiple range and multiple F-test Biometrics, 11:1-42

9-Nguyen thi . A., Hung, L. T., Lan, L. T. T., Phong, N. H., Loc, H. T., Anh, L. H.,. T. (2021). The Association between POU1F1 Gene Polymorphisms and Growth as well as Carcass Traits of Noi Native Chickens. Journal of Advanced Veterinary Research, 11(1), 36-40

10-Nie, Q., Fang, M., Xie, L., Zhou, M., Liang, Z., Luo, Z., ... \& Zhang, X. (2008). The PIT1 gene polymorphisms were associated with chicken growth traits. BMC genetics, 9(1), 1-5

11-Rodbari, Z., Alipanah, M., Seyedabadi, H. R., \& Amirinia, C. (2011). Identification of a single nucleotide polymorphism of the pituitary-specific transcriptional factor 1 (Pit 1) gene and its association with body composition trait in Iranian commercial broiler line. African Journal of Biotechnology, 10(60), 12979-12983. 


\section{University of Thi-Qar Journal of agricultural research}

ISSN Onlin:2708-9347, ISSN Print: 2708-9339 Volume 10, Issue 1 (2021) PP 25-38

https://jam.utq.edu.iq/index.php/main $\quad$ https://doi.org/10.54174/UTJagr.Vo10.N1./03

12-Bhattacharya, T. K., Chatterjee, R. N., \& Priyanka, M. (2012). Polymorphisms of Pit-1 gene and its association with growth traits in chicken. Poultry Science, 91(5), 1057-1064

13- AL-kreem, I. Q., Muhammad, M. F., \& AL-Anbari, N. N. (2017) Association of Growth hormone gene polymorphisms (T3199C) SNP on productive and physiological performance in Hubbard broiler chicken Journal of Kerbala for Agricultural Sciences, 4(3), 25-36

14-AL-Anbari(2019). Polymorphism of PIT 1 gene in broiler ROSS 308 hybrid and its association on some productive performance body scales. Toxicology and Endocrinology, 119(3), 305-315.

15-Manjula, P., Choi, N., Seo, D., \& Lee, J. H. (2018). POU class 1 homeobox 1 gene polymorphisms associated with growth traits in Korean native chicken. Asian-Australasian journal of animal sciences, 31(5), 643-649. https://doi.org/10.5713/ajas.17.0354 